\title{
Type II cGMP-dependent protein kinase inhibits EGF-induced JAK/STAT signaling in gastric cancer cells
}

\author{
MIN WU, YAN WU, TING LAN, LU JIANG, HAI QIAN and YONGCHANG CHEN \\ Department of Physiology, School of Medicine, Jiangsu University, Zhenjiang, Jiangsu 212013, P.R. China
}

Received June 20, 2015; Accepted June 7, 2016

DOI: $10.3892 / \mathrm{mmr} .2016 .5452$

\begin{abstract}
Previous research has demonstrated that type II cyclic guanosine monophosphate (cGMP)-dependent protein kinase (PKG II) inhibited epidermal growth factor (EGF)-initiated signal transduction of MAPK-mediated, PI3K/Akt-mediated and PLC $\gamma 1$-mediated pathways through blocking EGF-induced phosphorylation/activation of EGF receptor (EGFR). As EGF/EGFR signaling also initiated signal transduction of the Janus kinase (JAK)/signal transducer and activator of transcription (STAT)-mediated pathway, the present study was performed to investigate whether PKG II exerts an inhibitory effect this pathway. AGS human gastric cancer cell line was infected with adenoviral constructs encoding the cDNA of PKG II (Ad-PKG II), to increase the expression of PKG II, and treated with 8-pCPT-cGMP to activate the kinase. Western blotting was performed to detect the phosphorylation/activation of EGFR, JAK1, JAK2, STAT1 and STAT3 and the expression of cell cycle-associated proteins, including cyclin D1 and cyclin E. EGF-induced cell cycle changes were detected by flow cytometry. Transcriptional activity was determined by a reporter gene assay. The results demonstrated that EGF treatment increased the phosphorylation of EGFR, JAK1, JAK2, STAT1 and STAT3, increased the expression levels of cyclin D1 and cyclin E, promoted the cells to enter $\mathrm{S}$ phase, and stimulated transcriptional activity in the cells. Increased PKG II activity through infecting the cells with Ad-PKG II and activating the kinase with 8-pCPT-cGMP efficiently reversed the changes caused by EGF. The results suggest that PKG II inhibits EGF-induced signal transduction of the JAK/STAT-mediated pathway and further confirms that PKG II may be a cancer inhibitor.
\end{abstract}

Correspondence to: Professor Yongchang Chen, Department of Physiology, School of Medicine, Jiangsu University, 301 Xuefu Road, Zhenjiang, Jiangsu 212013, P.R. China

E-mail: ycchen54@ujs.edu.cn

Key words: cell cycle, EGFR, gastric cancer cells, JAK, PKG II, STAT

\section{Introduction}

Janus kinase (JAK)-signal transducer and activator of transcription (STAT)-mediated signal transduction pathway is important for regulating DNA transcription and the activities of the cell cycle. This pathway has three main signaling components: Receptors, JAK, and STAT (1). Extracellular signal molecules, including interferon, interleukin and growth factors, can bind with their receptors and cause activation of the kinase function of JAK through auto-phosphorylation. Consequently, STAT binds to the phosphorylated receptor, where it is phosphorylated by JAK. The phosphorylated STAT protein then binds to another phosphorylated STAT protein to form STATs dimer complex. The complex can be translocated into the nucleus and there it binds to DNA, promotes transcription of genes and causes the expression of proteins that affect basic cell activities, including cell growth, differentiation and death (2).

Type II cyclic guanosine monophosphate (cGMP)- dependent protein kinase (PKG II) is a serine/threonine kinase. It was identified $>30$ years ago and has been typically implicated only in several physiological functions, including intestinal secretion, bone growth, and learning and memory (3). However, increasing evidence has demonstrated that this kinase is involved in regulating proliferation and apoptosis of cells, and is potentially associated with tumorigenesis. For example, research data demonstrated that PKG II inhibited proliferation and/or induced apoptosis of human prostate cells, neruoglioma cells and breast cancer cells (4-6). Additionally, the inhibitory effect of PKG II on gastric cancer cells for several years has been investigated. An important finding was that PKG II blocks the activation of epidermal growth factor receptor (EGFR), the initiating event of the epidermal growth factor (EGF)-induced signal transduction process $(7,8)$. As the activation of EGFR can initiate the signal transduction of several pathways, including phospholipase $\mathrm{C} \gamma$-mediated, phosphatidylinositol 3-kinase (PI3K)/Akt serine/threonine kinase 1 (Akt)-mediated and JAK-STAT-mediated pathways (9-11), it is expected that the blockage of the EGFR activation by PKG II will inhibit the corresponding signal transductions and exert a wide-range of effects on the biological activities of cancer cells. The present study was performed to investigate the inhibitory effect of PKG II on EGF/EGFR-initiated signal transduction of the JAK-STAT-mediated pathway. 
A
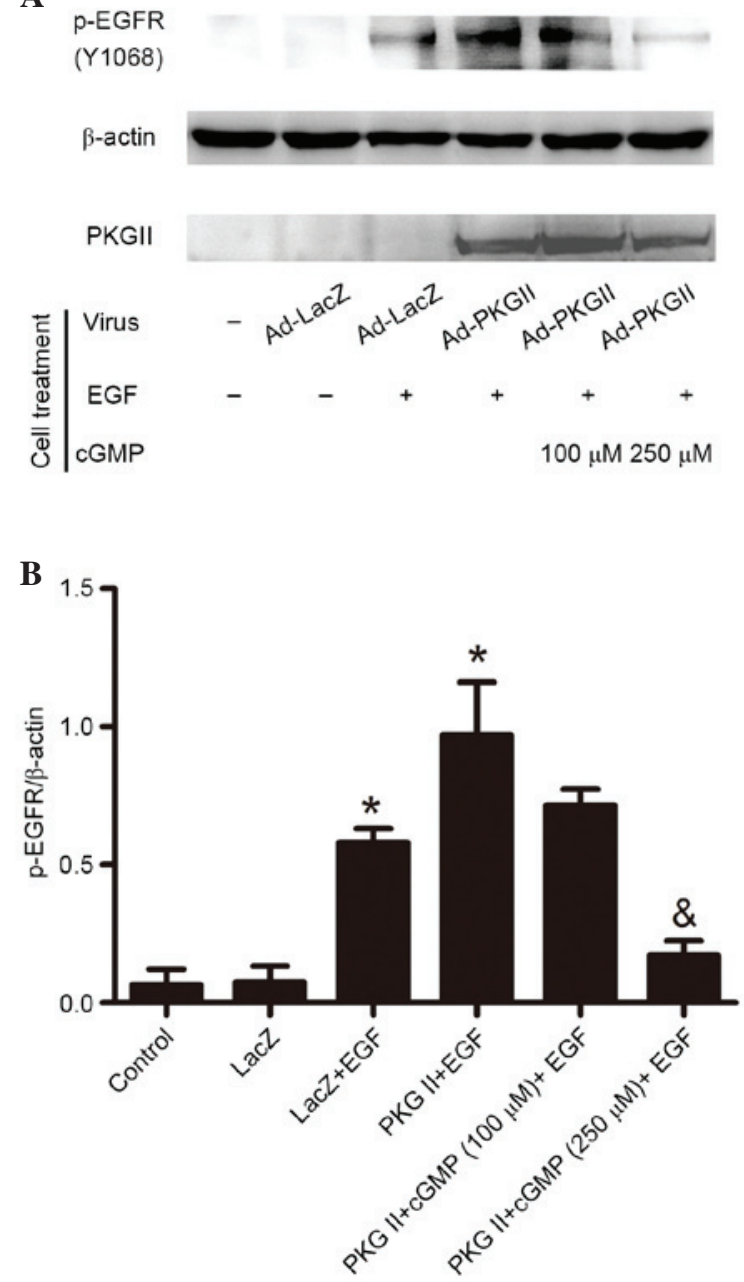

Figure 1.PKG II inhibits EGF-induced Y1068 phosphorylation of EGFR. AGS cells were infected with Ad-LacZ or Ad-PKG II for $24 \mathrm{~h}$ and serum-starved overnight. In LacZ + EGF and PKG II + EGF groups, cells were incubated with $100 \mathrm{ng} / \mathrm{ml} \mathrm{EGF}$ for $5 \mathrm{~min}$. In Ad-PKG II+cGMP + EGF groups, cells were treated with 8-pCPT-cGMP (100 or $250 \mu \mathrm{M})$ for $1 \mathrm{~h}$ and then with EGF $(100 \mathrm{ng} / \mathrm{ml})$ for $5 \mathrm{~min}$. (A) The cells were harvested and lysed as described in material and methods and the cell lysate was subjected to western blotting with antibody against p-EGFR (Tyr1068) to detect the phosphorylation of EGFR. $\beta$-actin was detected as a loading control and PKG II was detected to demonstrate the efficiency of the infection with Ad-PKG II. (B) Densitometry analysis was performed to quantify the positive bands and the ratio of $\mathrm{p}$-EGFR $/ \beta$-actin was determined. The data are presented as the mean \pm standard deviation from 3 independent experiments ${ }^{*} \mathrm{P}<0.05$ vs. control group and LacZ group; ${ }^{\circledR} \mathrm{P}<0.05$ vs. LacZ + EGF group and PKG II+EGF group. $\mathrm{p}$, phosphorylated; EGFR, epidermal growth factor receptor; PKG II, type II cGMP-denpendent protein kinase; Ad, adenovirus; LacZ, $\beta$-galactosidase; EGF, epidermal growth factor; cGMP, cyclic guanosine monophosphate.

\section{Materials and methods}

Cell line and reagents. AGS human gastric cancer cell line was provided by the Institute of Cell Biology (Shanghai, China). Adenoviral vectors encoding the cDNA of $\beta$-galactosidase ( $\beta$-gal) and PKG II (Ad-LacZ and Ad-PKG II, respectively), as well as the SRE-luc plasmid, RSV- $\beta$-gal plasmid and CMV vector plasmid were gifts from Dr Gerry Boss and Dr Renate Pilz (University of California, San Diego, CA, USA). Dulbecco's modified Eagle's media (DMEM) and fetal bovine serum (FBS) were obtained from Gibco (Thermo Fisher Scientific, Inc., Waltham, MA, USA).
A

p-JAK1

$\beta$-actin
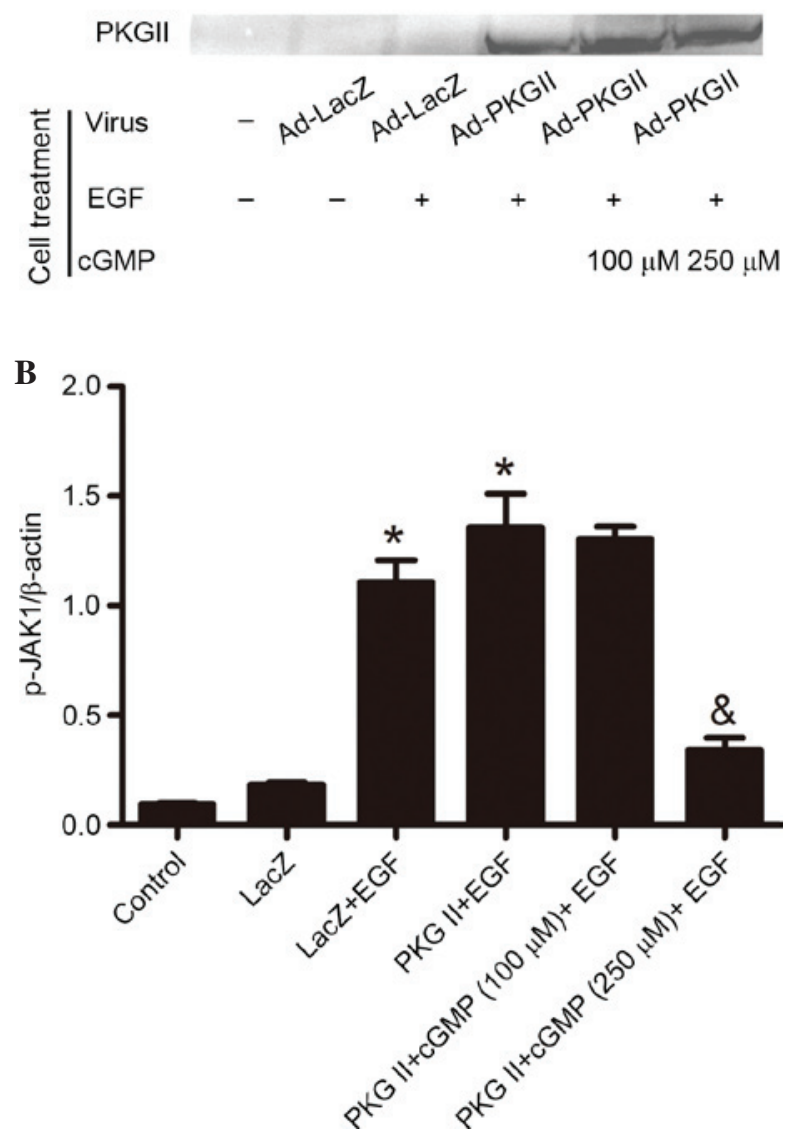

Figure 2. PKG II inhibits EGF-induced Tyr1022 phosphorylation of JAK1. (A) AGS cells were treated and the cell lysate was subjected to western blotting with antibody against p-JAK1 (Tyr1022) to detect the Tyr1022 phosphorylation of JAK1. $\beta$-actin was detected as a loading control and PKG II was detected to demonstrate the efficiency of the infection with Ad-PKG II. (B) Densitometry analysis was performed to quantify the positive bands and the ratio of $\mathrm{p}-\mathrm{JAK} 1 / \beta$-actin was determined. The data are presented as the mean \pm standard deviation from 3 independent experiments. ${ }^{*} \mathrm{P}<0.05$ vs. control group and LacZ group; ${ }^{\circledR} \mathrm{P}<0.05 \mathrm{vs}$. LacZ + EGF group and PKG II + EGF group. p-, phosphorylated; JAK1, Janus kinase 1; PKG II, type II cGMP-denpendent protein kinase; Ad, adenovirus; LacZ, $\beta$-galactosidase; EGF, epidermal growth factor; cGMP, cyclic guanosine monophosphate.

Polyclonal rabbit antibody against PKG II was purchased from Abgent, Inc. (San Diego, CA, USA; cat no. AP8001a; dilution, 1:200). Monoclonal mouse anti- $\beta$-actin antibody was purchased from Santa Cruz Biotechnology, Inc. (Dallas, TX, USA; cat no. sc-47778; dilution, 1:1,000). Polyclonal rabbit anti-phosphorylated (p)-EGFR (Tyr1068) was obtained from Cell Signaling Technology, Inc. (Danvers, MA, USA; cat no. 2236; dilution, 1:1,000). Polyclonal rabbit anti-p-JAK1 (cat no. BS4108; dilution, 1:500), anti-p-JAK2 (cat no. BS4109; dilution, 1:500), anti-p-STAT1 (cat no. BS4178; dilution, 1:500) and anti-p-STAT3 (cat. no. BS4180; dilution, 1:500) antibodies were purchased from Bioworld Technology, Inc. (St. Louis Park, MN, USA). Monoclonal mouse anti-cyclin D1 (cat. no. BMO771; dilution, 1:400) and polyclonal rabbit anti-cyclin E (cat no. BAO774; dilution, 1:400) 
A
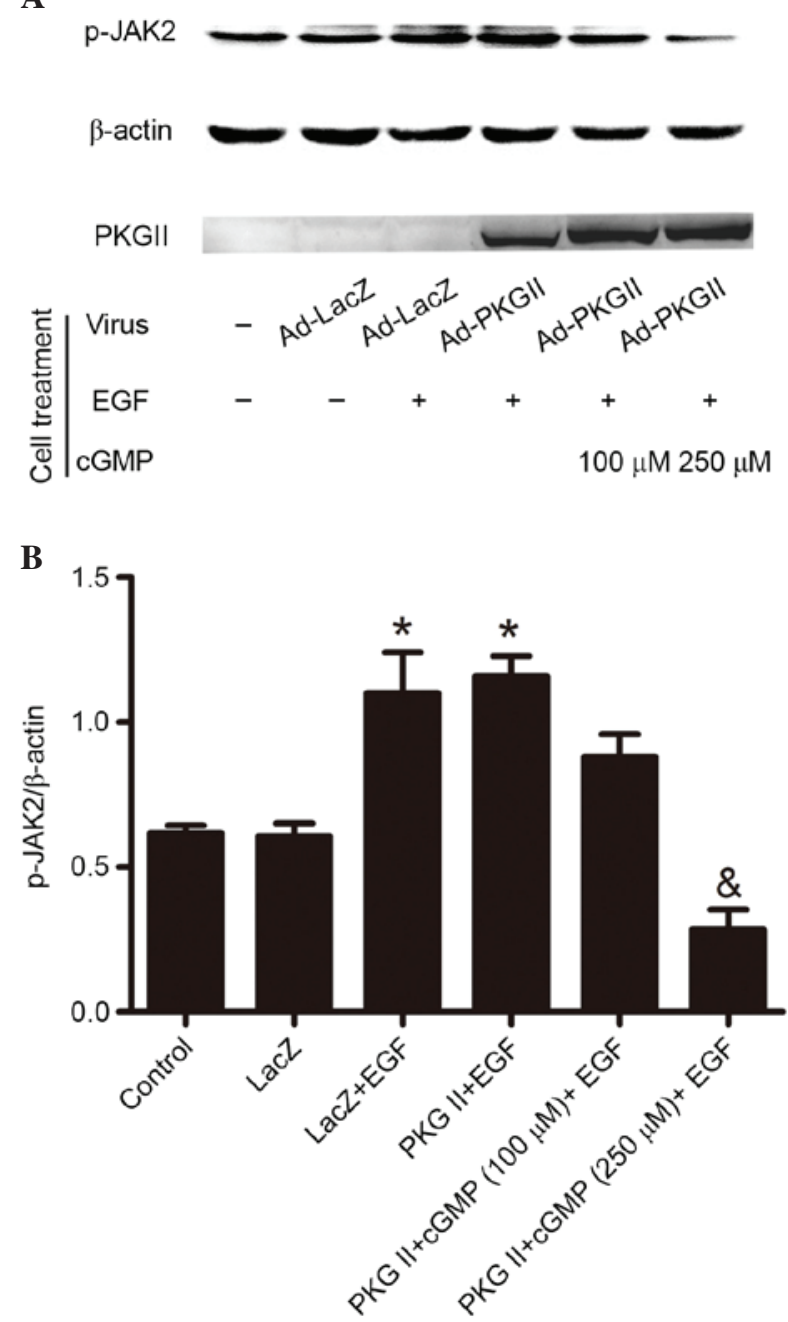

Figure 3. PKG II inhibits EGF-induced Tyr 1007/Tyr 1008 phosphorylation of JAK2. (A) AGS cells were treated same as in Fig. 1 and the cell lysate was subjected to Western blotting with antibody against p-JAK2 (Tyr 1007/Tyr 1008) to detect the Tyr 1007/Tyr 1008 phosphorylation of JAK2 $\beta$-actin was detected as loading control and PKG II was detected to show the efficiency of the infection with Ad-PKG II. (B) Densitometry analysis was performed to quantify the positive bands and the ratio of p-JAK2/ $\beta$-actin was determined. The data are presented as the mean \pm standard deviation from 3 independent experiments. ${ }^{*} \mathrm{P}<0.05$ vs. control group and LacZ group; ${ }^{\circledR} \mathrm{P}<0.05$ vs. LacZ + EGF group and PKG II + EGF group. p-, phosphorylated; JAK2, Janus kinase 2; PKG II, type II cGMP-denpendent protein kinase; Ad, adenovirus; LacZ, $\beta$-galactosidase; EGF, epidermal growth factor; cGMP, cyclic guanosine monophosphate.

antibodies were from Wuhan Boster Biological Technology, Ltd. (Wuhan, China). Horseradish peroxidase-conjugated goat anti-mouse (cat. no. 115-035-003) and goat anti-rabbit (cat. no. 111-035-003) polyclonal secondary antibodies (dilution, 1:10,000) were from Jackson ImmunoResearch Laboratories, Inc. (West Grove, PA, USA). The cellular permeable cGMP analog, 8-pCPT-cGMP, was from EMD Millipore (Billerica, MA, USA). EGF was obtained from Sigma-Aldrich (St. Louis, MO, USA). Electrochemiluminescence (ECL) reagents were from EMD Millipore. All other reagents used were of analytical grade.

Cell culture and preparation of cell extracts. AGS cells were cultured in DMEM supplemented with 10\% FBS and
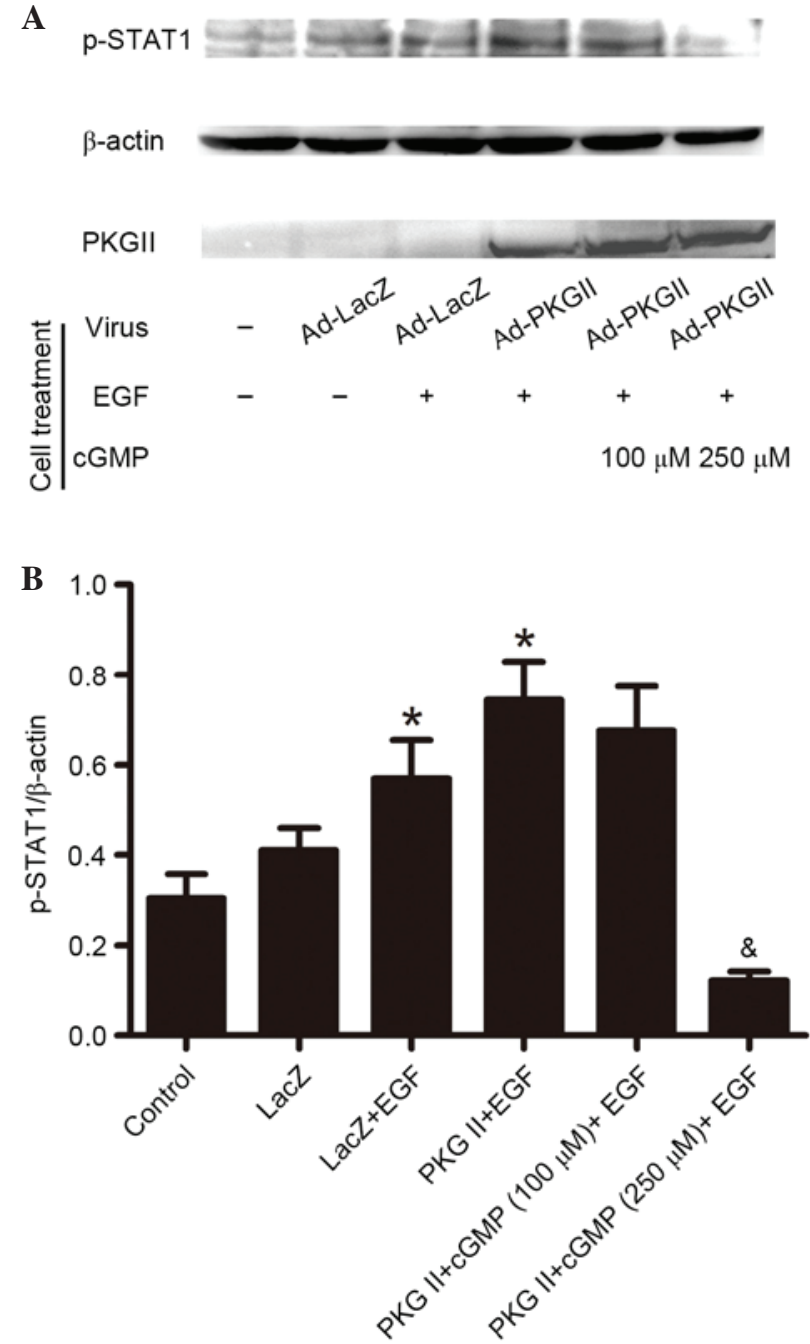

Figure 4. PKG II inhibits EGF-induced Tyr701 phosphorylation of STAT1. (A) AGS cells were treated and the cell lysate was subjected to western blotting with antibody against p-STAT1 (Tyr701) to detect the Tyr701 phosphorylation of STAT1. $\beta$-actin was detected as loading control and PKG II was detected to demonstrate the efficiency of the infection with Ad-PKG II. (B) Densitometry analysis was performed to quantify the positive bands and the ratio of p-STAT $1 / \beta$-actin was determined. The data are presented as the mean \pm standard deviation from 3 independent experiments. ${ }^{*} \mathrm{P}<0.05$ vs. control group and LacZ group; ${ }^{\circledR} \mathrm{P}<0.05$ vs. LacZ + EGF group and PKG II + EGF group. p-, phosphorylated; STAT1, signal trasducer and activator of transcription 1; PKG II, type II cGMP-denpendent protein kinase; Ad, adenovirus; LacZ, $\beta$-galactosidase; EGF, epidermal growth factor; cGMP, cyclic guanosine monophosphate.

maintained at $37^{\circ} \mathrm{C}$ in a humidified incubator, with $95 \%$ air and $5 \% \mathrm{CO}_{2}$. On the day prior to infection, cells were plated into 6-well plates. When the cells were 70-80\% confluent, they were infected with Ad-LacZ or Ad-PKG II with a MOI of $100 \%$ or mock infected. At $24 \mathrm{~h}$ after the infection, the medium was replaced with serum-free medium, and the culture was continued for $12 \mathrm{~h}$. The infected cells were incubated with 100 or $250 \mu \mathrm{M} 8$-pCPT-cGMP for $1 \mathrm{~h}$, and were then incubated with $100 \mathrm{ng} / \mathrm{ml}$ EGF. To observe the phosphorylation of EGFR, the EGF incubation time was $5 \mathrm{~min}$; to observe the change of protein expression, the EGF incubation time was $12 \mathrm{~h}$. Differently treated cells were harvested at various times by aspiration of the media and direct addition of heated $2 \mathrm{X}$ sodium dodecyl sulfate (SDS) sample buffer. The cell 

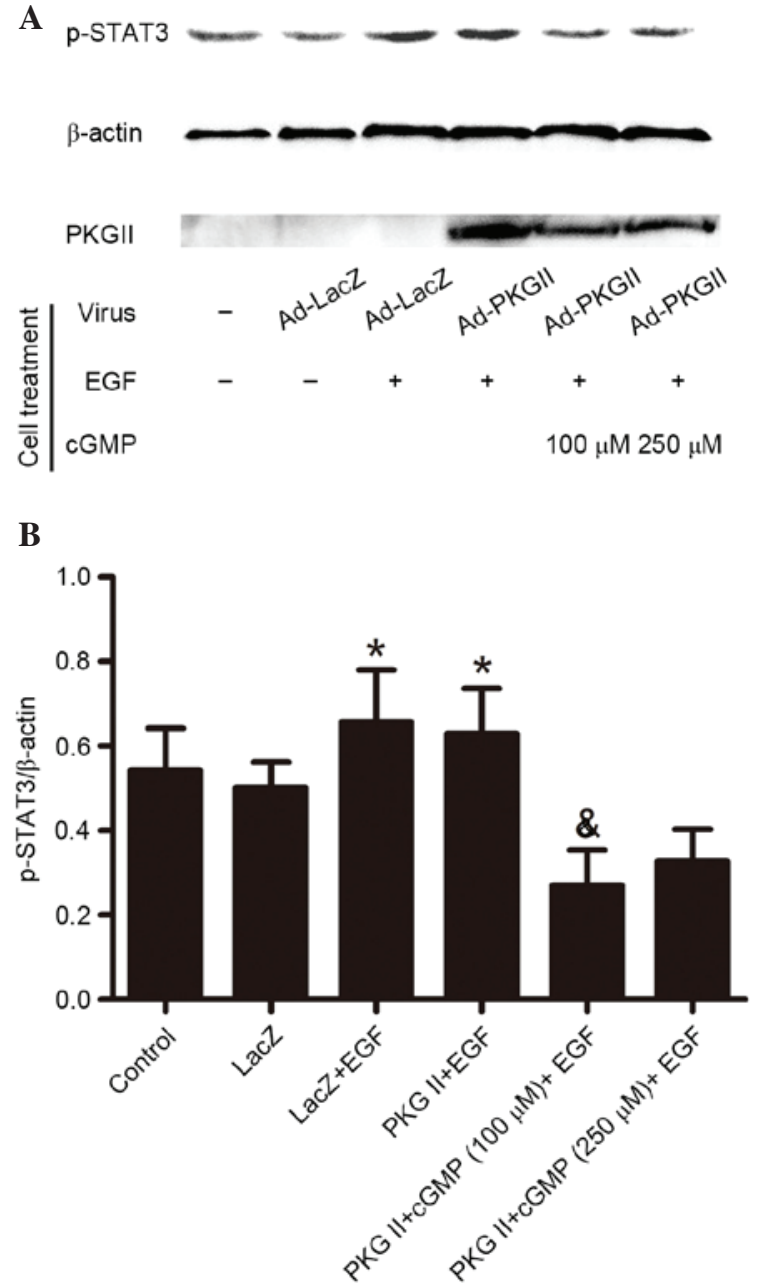

Figure 5. PKG II inhibits EGF-induced Tyr705 phosphorylation of STAT3. (A) AGS cells were treated sand the cell lysate was subjected to western blotting with antibody against p-STAT3 (Tyr705) to detect the Tyr705 phosphorylation of STAT3. $\beta$-actin was detected as loading control and PKG II was detected to show the efficiency of the infection with Ad-PKG II. (B) Densitometry analysis was performed to quantify the positive bands and the ratio of $\mathrm{p}$-STAT3/ $\beta$-actin was determined. The data are presented as the mean \pm standard deviation from 3 independent experiments. ${ }^{*} \mathrm{P}<0.05$ vs. control group and LacZ group; ${ }^{\circledR} \mathrm{P}<0.05$ vs. LacZ + EGF group and PKG II + EGF group. p-, phosphorylated; STAT3, signal trasducer and activator of transcription 3; PKG II, type II cGMP-denpendent protein kinase; Ad, adenovirus; LacZ, $\beta$-galactosidase; EGF, epidermal growth factor; cGMP, cyclic guanosine monophosphate.

lysate was scraped and transferred to Eppendorf tube, heated for $5 \mathrm{~min}$ at $100^{\circ} \mathrm{C}$ and stored at $-20^{\circ} \mathrm{C}$.

Western blotting. A Bicinchoninic Acid Protein Assay was used to quantify the protein concentration of the cellular extract. Then, $10 \mu \mathrm{g}$ protein was loaded onto each lane and proteins were separated by SDS-polyacrylamide gel electrophoresis (8-12\%) gel according to the molecular size, and transferred onto a polyvinylidene fluoride membrane. Blots were blocked with $5 \%(\mathrm{w} / \mathrm{v})$ nonfat milk in Tris-buffered saline-Tween 20 for $1 \mathrm{~h}$ at room temperature, and then incubated at $4^{\circ} \mathrm{C}$ overnight with the primary antibody, followed by incubation with the secondary antibody at room temperature for $1 \mathrm{~h}$. The signal was visualized by using the ECL detection reagents. To perform densitometry analysis, digital images of the positive

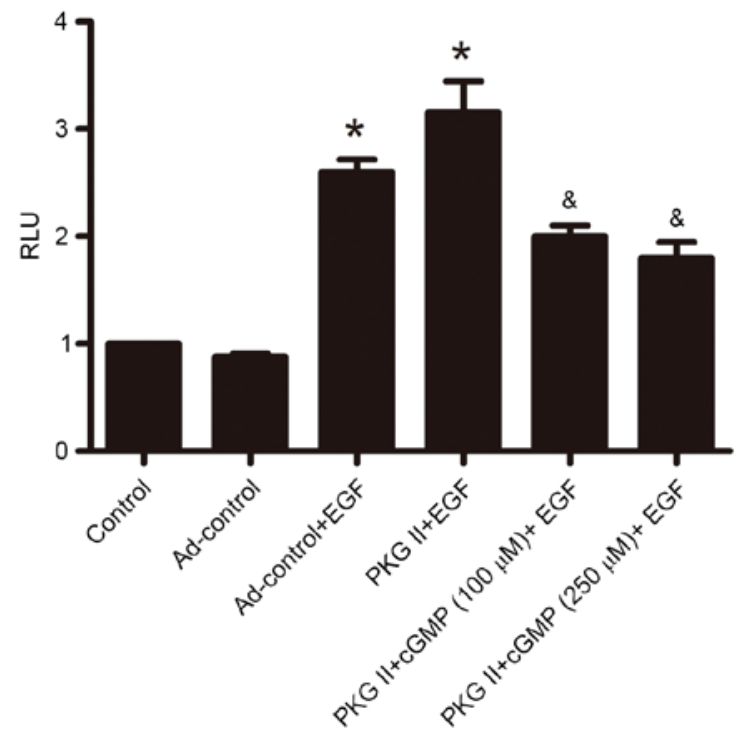

Figure 6. PKG II inhibits SRE-dependent transcription initiated by EGF. AGS cells were transfected with plasmid DNA mixture for $8 \mathrm{~h}$ and infected with Ad-LacZ or Ad-PKG II for $24 \mathrm{~h}$, serum-starved overnight, and treated as follows: In Ad-LacZ + EGF and Ad-PKG II + EGF groups, cells were incubated with EGF (100 ng/ml) for $12 \mathrm{~h}$; in Ad-PKG II + cGMP groups, cells were incubated with 100 or $250 \mu \mathrm{M} 8$-pCPT-cGMP respectively for $1 \mathrm{~h}$, and then incubated with EGF for $12 \mathrm{~h}$. The cell lysate was prepared and reporter gene assay was applied to detect the SRE-dependent transcription activity. The results were presented as RLU (luciferase/LacZ). The data are presented as the mean \pm standard deviation from 3 independent experiments. ${ }^{*} \mathrm{P}<0.05$ vs. control group and LacZ group; ${ }^{\circledR} \mathrm{P}<0.05$ vs. LacZ + EGF group and PKG II + EGF group. Ad, adenovirus; EGF, epidermal growth factor; PKG II, type II cGMP-denpendent protein kinase; LacZ, $\beta$-galactosidase; cGMP, cyclic guanosine monophosphate.

bands were obtained with a Chemidoc XRS and analyzed using the image analysis program Quantity One v4.4.0.36 (Bio-Rad Laboratories, Inc., Hercules, CA, USA). The results were presented as the ratio of target protein/loading control.

Transient transfection and luciferase reporter assays. Plasmids were purified with a Qiagen Plasmid Purification Kit (Qiagen GmbH, Hilden, Germany). Transient transfections were performed using Lipofectamine 2000 (Invitrogen; Thermo Fisher Scientific, Inc.), initially using 70-80\% confluent cells/well in 24-well plate with $0.6 \mu \mathrm{g}$ of plasmid DNA mixture, following the manufacturer's instructions. For each well, AGS cells were transfected with $0.1 \mu \mathrm{g}$ SRE-luc plasmid DNA, $0.1 \mu \mathrm{g}$ RSV- $\beta$-Gal plasmid DNA and $0.4 \mu \mathrm{g}$ CMV-vector plasmid DNA. After $8 \mathrm{~h}$ of incubation, the serum-free medium was replaced with fresh medium containing $10 \%$ serum and cells were infected with adenoviral vectors as described above. After $36 \mathrm{~h}$ of incubation, cells were washed with phosphate-buffered saline (PBS) and harvested, then luciferase assays were performed. The luciferase and $\beta$-gal activities of the lysates were measured using a chemiluminescence detector (Berthold Technologies GmbH, Zug, Switzerland). Transcription factor activity was reported in relative light units (RLU, luciferase/ $\beta$-gal). All experiments were performed independently at least three times, with two parallels.

Cell cycle analysis. Cells were plated into 6-well plates and infected with adenoviral vectors as described above. The cells 
A
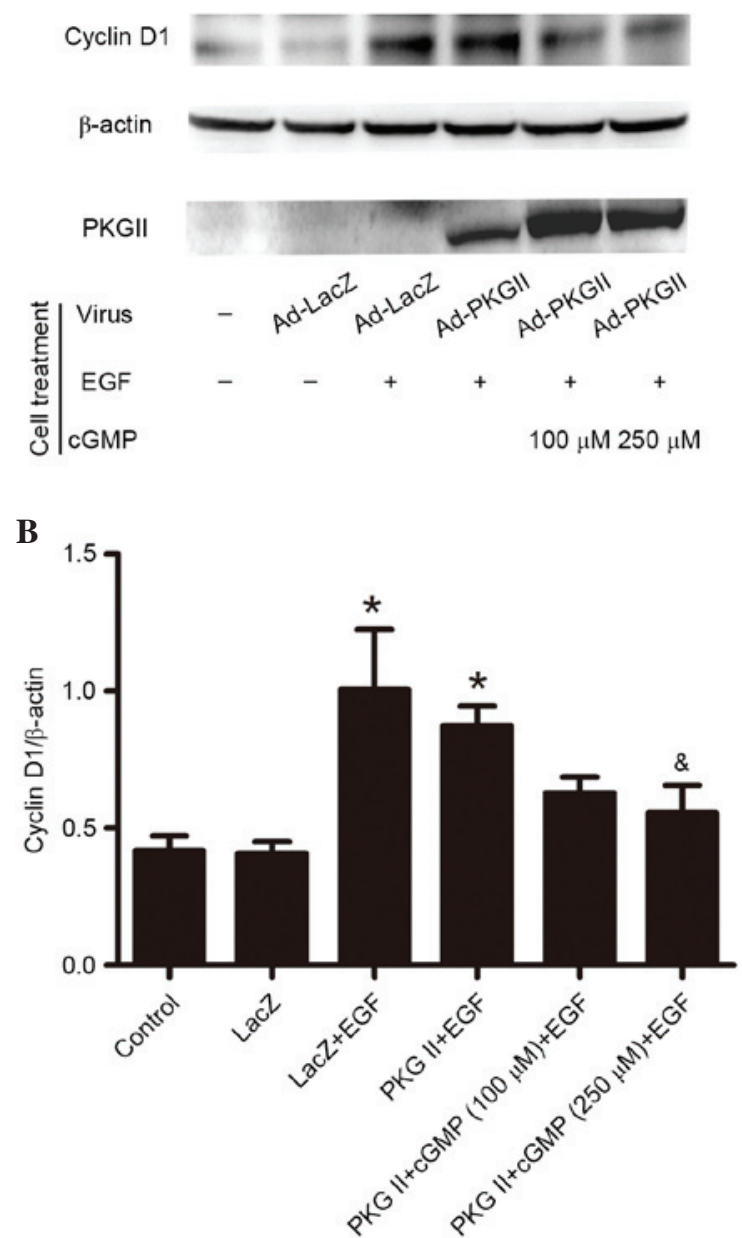

Figure 7. PKG II inhibits EGF-induced expression of cyclin D1. AGS cells were infected with either Ad-LacZ or Ad-PKG II, serum starved overnight, and treated differently: In Ad-LacZ group, no drug treatment; in Ad-LacZ + EGF group, the cells were incubated with EGF $(100 \mathrm{ng} / \mathrm{ml})$ for $12 \mathrm{~h}$; in Ad-PKG II + cGMP + EGF group, cells were incubated with 100 or $250 \mu \mathrm{M} 8$-pCPT-cGMP for $1 \mathrm{~h}$ and followed by incubating with EGF $(100 \mathrm{ng} / \mathrm{ml})$ for $12 \mathrm{~h}$. (A) The cell lysate was subjected to western blotting to detect the expression of cyclin D1. $\beta$-actin was detected as a loading control and PKG II was detected to demonstrate the efficiency of the infection with Ad-PKG II. (B) Densitometry analysis was performed to quantify the positive bands and the ratio of Cylin D $1 / \beta$-actin was determined. The data are presented as the mean \pm standard deviation from 3 independent experiments. ${ }^{*} \mathrm{P}<0.05$ vs. control group and LacZ group; ${ }^{\circledR} \mathrm{P}<0.05$ vs. LacZ + EGF group and PKG II + EGF group. PKG II, type II cGMP-denpendent protein kinase Ad, adenovirus; LacZ, $\beta$-galactosidase; EGF, epidermal growth factor; cGMP, cyclic guanosine monophosphate.

at the logarithmic growth phase were trypsinized, washed with PBS twice, and then fixed with $70 \%$ ethanol at $4{ }^{\circ} \mathrm{C}$ overnight. The fixed cells were washed with PBS twice, re-suspended in $400 \mu \mathrm{l}$ PBS (containing $50 \mu \mathrm{g} / \mathrm{ml}$ ribonuclease A and $50 \mu \mathrm{g} / \mathrm{ml}$ propidium iodide), and incubated in an ice bath away from light for $30 \mathrm{~min}$. The cell cycle distribution was detected using the FACSCalibur flow cytometer (BD Biosciences, Franklin Lakes, NJ, USA). All experiments were performed independently at least three times.

Statistical analysis. The data are expressed as the means \pm standard deviation. Statistical significance was detected using one way analysis of variance followed by
A
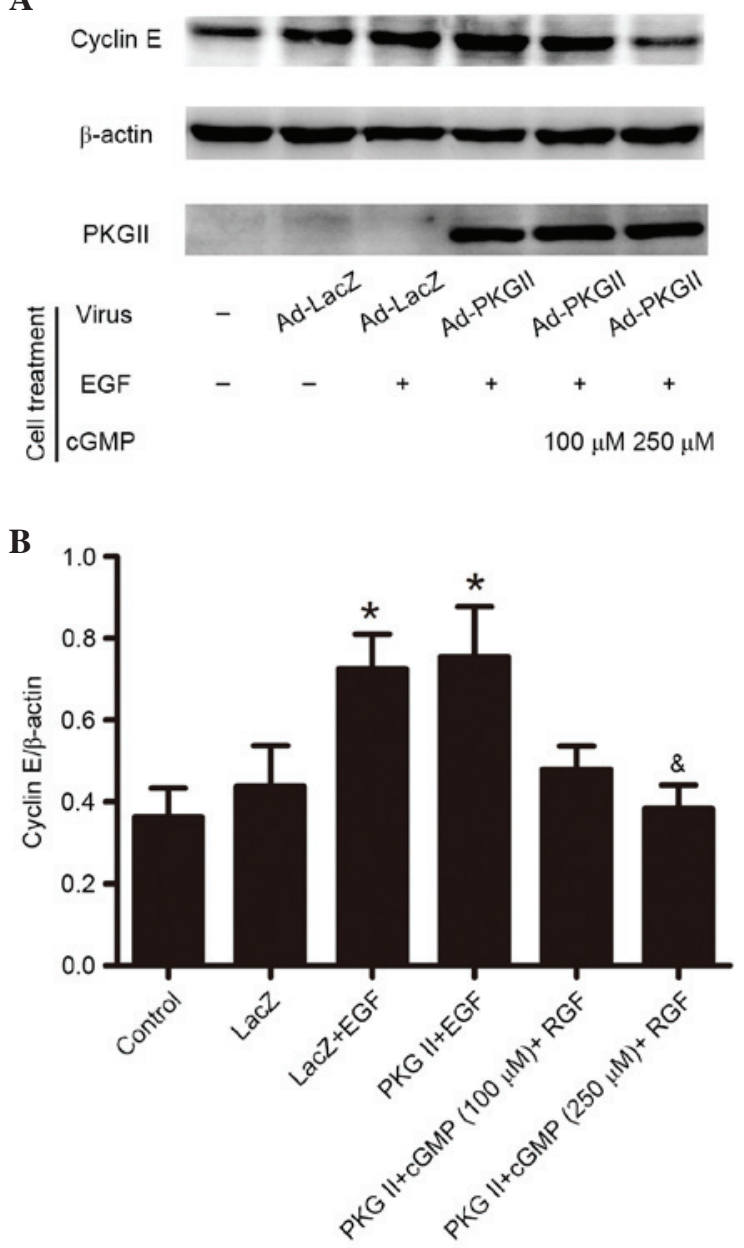

Figure 8. PKG II inhibits EGF-induced expression of Cyclin E. AGS cells were treated as descripbed in Fig. 7. (A) The cell lysate was subjected to western blotting to detect the expression of cyclin E. $\beta$-actin was detected as loading control and PKG II was detected to show the efficiency of the infection with Ad-PKG II. (B) Densitometry analysis was performed to quantify the positive bands and the ratio of Cylin $\mathrm{E} / \beta$-actin was determined. The data are presented as the mean \pm standard deviation from 3 independent experiments. ${ }^{*} \mathrm{P}<0.05$ vs. control group and LacZ group; ${ }^{\&} \mathrm{P}<0.05$ vs. LacZ + EGF group and PKG II + EGF group. PKG II, type II cGMP-denpendent protein kinase; Ad, adenovirus; LacZ, $\beta$-galactosidase; EGF, epidermal growth factor; cGMP, cyclic guanosine monophosphate.

Student-Neuman-Keuls method with SPSS statistical software (version 17.0; SPSS, Inc., Chicago, IL, USA). P<0.05 was considered to indicate a statistically significant difference.

\section{Results}

PKG II inhibits EGF-induced Tyr1068 phosphorylation of EGFR. Tyr1068 is one of the important auto-phosphorylation sites of EGFR. Phosphorylation of this site is associated with JAK/STAT-mediated signaling (12). In the current study, western blotting with antibody against p-EGFR (Tyr1068) was performed to investigate the inhibitory effect of PKG II on Tyr1068 phosphorylation of EGFR in differently treated AGS cells. The results demonstrated that EGF treatment (100 $\mathrm{ng} / \mathrm{ml}, 5 \mathrm{~min}$ ) caused a significant increase in EGFR Tyr1068 phosphorylation compared with the control and Ad-LacZ group $(\mathrm{P}=0.001$, the $\mathrm{PKG}$ II+EGF group vs. the control group; $\mathrm{P}=0.001$, the $\mathrm{LacZ}+\mathrm{EGF}$ group vs. the LacZ 

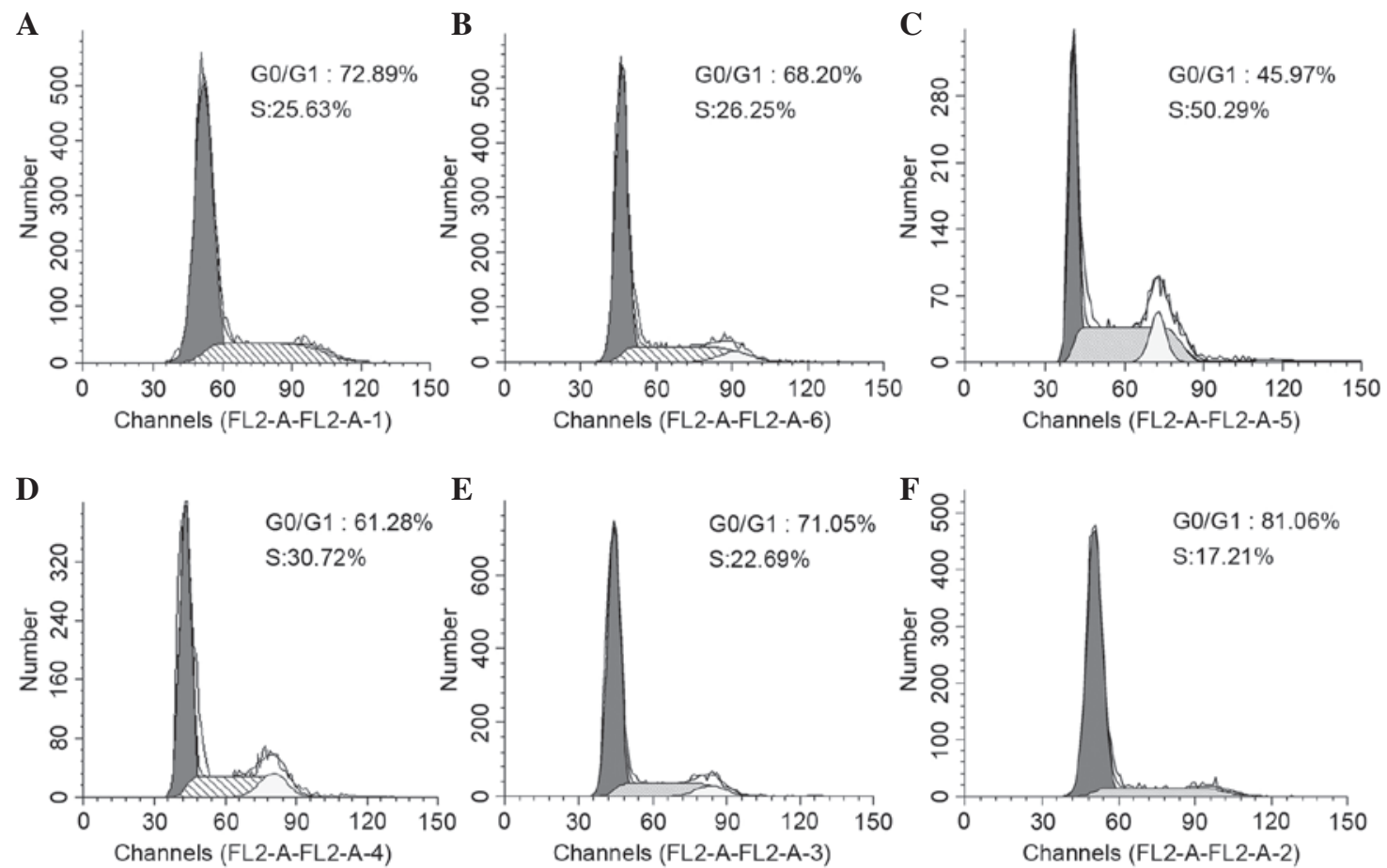

Figure 9. PKG II inhibits EGF-induced change of cell cycle. AGS cells were treated same as described in Fig. 7. Cytometry was applied to detect the change of cell cycle. (A) control; (B) Ad-LacZ; (C) Ad-LacZ + EGF; (D) Ad-PKG II + EGF; (E) Ad-PKG II + 8-pCPT-cGMP $100 \mu$ M + EGF; (F) Ad-PKG $\mathrm{II}+8$-pCPT-cGMP $250 \mu \mathrm{M}+$ EGF. Data are presented as the mean \pm standard deviation from 3 independent experiments. $\mathrm{P}<0.05$, the LacZ+EGF group vs. the control group; P<0.05, the PKG II+cGMP $(100 \mu \mathrm{M})+$ EGF group vs. the PKG II+EGF group. PKG II, type II cGMP-denpendent protein kinase; EGF, epidermal growth factor; Ad, adenovirus; LacZ, $\beta$-galactosidase; cGMP, cyclic guanosine monophosphate.

group). In cells infected with Ad-PKG II and stimulated with 8-pCPT-cGMP (100 or $250 \mu \mathrm{M}, 1 \mathrm{~h}$ ), the EGF-induced phosphorylation was significantly decreased compared with the PKG II + EGF group ( $\mathrm{P}=0.003$, the PKG II+cGMP+EGF group vs. the PKG II+EGF group; Fig. 1). This indicated that PKG II inhibited the activation of EGFR caused by EGF.

PKG II inhibits EGF-induced phosphorylation of JAKI and JAK2. Western blotting with antibody against p-JAK1 (Tyr1022) and p-JAK2 (Tyr1007/Tyr1008) was applied to detect the phosphorylation/activation of these kinases. The results demonstrated that EGF treatment $(100 \mathrm{ng} / \mathrm{ml}, 5 \mathrm{~min})$ increased the Tyr1022 phosphorylation of JAK1 (Fig. 2) and Tyr1007/1008 phosphorylation of JAK2 (Fig. 3). In cells infected with Ad-PKG II, stimulated with 8-pCPT-cGMP $(100$ or $250 \mu \mathrm{M}, 1 \mathrm{~h})$ and then treated with EGF $(100 \mathrm{ng} / \mathrm{ml}$, $5 \mathrm{~min}$ ), the phosphorylation level of JAK1 and JAK2 was significantly lower compared with cells infected with Ad-LacZ or Ad-PKG II and treated with EGF only ( $\mathrm{P}=0.007$, the PKG II+cGMP+EGF group vs. the PKG II+EGF group, Fig. 2; $\mathrm{P}=0.025$, the PKG II+cGMP+EGF group vs. the PKG II+EGF group, Fig. 3). These results demonstrated that PKG II inhibited the EGF-induced activation of JAKs.

PKG II inhibits EGF-induced phosphorylation of STAT1 and STAT3. Activated JAK can induce phosphorylation of STAT, which then binds with another phosphorylated STAT to form a dimer. This is an important step of JAK/STAT-mediated signaling (13). In current study, western blotting with antibodies against p-STAT1 (Tyr701) and p-STAT3 (Tyr705) was performed to detect the phosphorylation of STAT1 and STAT3 in cells. The results demonstrated that in cells infected with Ad-LacZ and treated with EGF (100 ng/ml, 5 min), Tyr701 phosphorylation of STAT1 (Fig. 4) and STAT3 (Fig. 5) was significantly increased $(\mathrm{P}=0.035$, the $\mathrm{PKG}$ II+EGF group vs. the control group; $\mathrm{P}=0.029$, the LacZ+EGF group vs. the LacZ group, Fig.4; $P=0.038$, the PKG II+EGF group vs. the control group; $\mathrm{P}=0.021$, the LacZ+EGF group vs. the LacZ group, Fig. 5) compared with control and untreated Ad-LacZ cells. In the cells infected with Ad-PKG II, stimulated with 8-pCPT-cGMP (100 or $250 \mu \mathrm{M}, 1 \mathrm{~h}$ ) and then treated with EGF (100 ng/ml, $5 \mathrm{~min})$, the phosphorylation level of STAT1 and STAT3 was significantly reduced compared with cells infected with Ad-LacZ and treated with EGF only $(\mathrm{P}=0.009$, the PKG II+cGMP+EGF group vs. the PKG II+EGF group, Fig.4; $\mathrm{P}=0.011$, the PKG II+cGMP+EGF group vs. the PKG II+EGF group, Fig. 5). These results indicated that PKG II inhibited the EGF-induced activation of STAT1 and STAT3.

PKG II inhibits the transcriptional activity caused by $E G F$. Dimerized STATs can move into the nucleus and associate with transcription factor to initiate transcriptional activity (13). To investigate the inhibitory effect of PKG II on EGF/EGFR-induced transcript activity, reporter gene assays were performed to detect the inhibition of PKG II on EGF/EGFR initiated transcription. The results demonstrated that EGF treatment $(100 \mathrm{ng} / \mathrm{ml}, 12 \mathrm{~h})$ significantly increased SRE-dependent transcriptional activity compared with the controls ( $\mathrm{P}=0.005$, $\mathrm{PKG}$ II+EGF group vs. the control group; $\mathrm{P}=0.008$, the LacZ+EGF group vs. the LacZ group). Additionally, increased of PKG II activity (infected with Ad-PKG II for 
$24 \mathrm{~h}$ and treated with 100 or $250 \mu \mathrm{M}$ cGMP for $1 \mathrm{~h}$ ) inhibited the stimulating effect of EGF/EGFR on transcriptional activity compared with EGF-treated Ad-PKG II cells ( $\mathrm{P}=0.033$, the PKG II+cGMP+EGF group vs. the PKG II+EGF group, Fig. 6).

PKG II inhibits EGF-induced expression of cyclin D1 and cyclin $E$. Activated STAT3 can upregulate the expression levels of various proteins involved in cell cycle progression, including Fos, c-Myc, and cyclin D (14). To investigate the inhibition of PKG II on EGF/EGFR-JAK/STAT signaling-induced expression of cell cycle-associated proteins, western blotting was performed to detect the expression of cyclin D1 (Fig. 7) and cyclin E (Fig. 8) in AGS cells. The results demonstrated that EGF treatment $(100 \mathrm{ng} / \mathrm{ml}, 12 \mathrm{~h})$ caused a significant increase in the expression levels of cyclin D1 and cyclin E compared with untreated controls $(\mathrm{P}=0.006$, the $\mathrm{PKG}$ II+EGF group vs. the control group; $\mathrm{P}=0.015$, the LacZ+EGF group vs. the LacZ group, Fig. 7; $\mathrm{P}=0.023$, the $\mathrm{PKG} \mathrm{II}+\mathrm{EGF}$ group vs. the control group; $\mathrm{P}=0.000$, the $\mathrm{LacZ}+\mathrm{EGF}$ group vs. the LacZ group, Fig. 8). The increased PKG II activity caused by infecting the cells with Ad-PKG II and stimulating with 8-pCPT-cGMP (100 or $250 \mu \mathrm{M}, 1 \mathrm{~h}$ ) significantly inhibited the EGF-induced expression of cyclin D1 and cyclin E compared with Ad-PKG II cells treated with EGF only (Figs. 7 and 8).

PKG II inhibits EGF-induced cell cycle progression. STAT3 activity is critical for a wide range of functions in numerous cell types, including cellular differentiation, cell-cycle progression, proliferation and survival (15). In the present study, flow cytometry was performed to detect the changes in the cell cycle in differently treated AGS cells. The data shown are the mean \pm SD from 3 independent experiments $(\mathrm{P}=0.028$, the LacZ+EGF group vs. the control group; $\mathrm{P}=0.016$, the PKG II+cGMP $(100 \mu \mathrm{M})+\mathrm{EGF}$ group vs. the PKG II+EGF group). The results demonstrated that EGF treatment $(100 \mathrm{ng} / \mathrm{ml}$, $12 \mathrm{~h}$ ) promoted cells to enter $\mathrm{S}$-phase, with the number of cells increased from 26.25\% (Ad-LacZ group) to $50.29 \%$ (Ad-LacZ + EGF group). The activation of PKG II (through infecting the cells with Ad-PKG II and treating the cells with 100 or $250 \mu \mathrm{M}$ cGMP for $1 \mathrm{~h}$ ) inhibited the effect of EGF, inducing a decrease from 50.29\% (Ad-LacZ + EGF group) to $22.69 \%$ (Ad-PKG II + 8-pCPT-cGMP $100 \mu \mathrm{M}$ group) and $17.21 \%$ (Ad-PKG II+8-pCPT-cGMP $250 \mu \mathrm{M}$ group; Fig. 9).

\section{Discussion}

JAKs, which exhibit tyrosine kinase activity, are associated with several types of cell surface receptors, including receptors for cytokines and growth factors. The binding of a ligand to the receptor triggers the activation of JAKs. With increased kinase activity, JAKs phosphorylate tyrosine residues on the receptor and create sites for interaction with proteins that contain phosphotyrosine-binding SH2 domains (1). STATs possess $\mathrm{SH} 2$ domains and, thus, are recruited to the receptors through binding with these phosphotyrosine residues. Receptor-bound STATs are phosphorylated by JAKs and the phospho-tyrosine then functions as binding site for SH2 domains of other STATs, mediating their dimerization. Different STATs form hetero or homodimers. Finally, activated STAT dimers accumulate in the cell nucleus and activate transcription of their target genes $(2,16)$. JAK-STAT-mediated signaling is associated with cell cycle activity. It may induce expression of cell cycle-associated proteins, including cyclins, and cause changes in the cell cycle (13). The abnormal signal transduction activity of this pathway is closely associated with tumorigenesis of multiple tumors, including gastric cancer (17-19).

EGFR is an important member of the receptor tyrosine kinase family. When a ligand, predominantly EGF, binds with EGFR, several signal transduction pathways can be initiated (9-11). EGFR is closely associated with tumorigenesis, and overexpression and mutation of EGFR occurs in the majority of cancers (20). In vitro experiments have previously confirmed that overexpression of EGFR caused transformation of NIH-3T3, Rat-1 and NRK cells, and blocking EGFR activation inhibited proliferation of certain tumor cells (21). Furthermore, clinical investigate has previously demonstrated that patients with cancer that overexpress of EGFR typically have poor prognosis. For example, EGFR overexpression was detected in $60 \%$ of patients with non-small cell lung cancer and the prognosis of the patients was poor, with survival of 4-5 months (22). Thus, EGFR is a potential cancer therapy target and the methods of inhibiting EGFR activity are of specific significance (23).

Previous results have demonstrated that PKG II inhibited EGF/EGFR-induced signal transduction of mitogen-activated protein kinase (MAPK)/extracellular signal-regulated kinase-mediated, MAPK/JNK-mediated, PLC $\gamma 1 /$ protein kinaseC-mediated andPI3K/Akt-mediated pathways $(7,8,24,25)$. In the current study, as a part of a series of studies, the inhibitory effect of PKG II on EGF/EGFR-induced signal transduction of the JAK/STAT-mediated signaling pathway was investigated. Tyr1068 is the phosphorylation site that is associated with activation of JAK/STAT-mediated signal transduction (12). The results of the current study demonstrated that the Tyr1068 phosphorylation level was significantly increased when the cells were stimulated with EGF, demonstrating the activation of EGFR and the initiation of JAK/STAT-mediated signaling. Increased PKG II activity efficiently inhibited this phosphorylation. For the important signaling components of this signal transduction pathway, including JAK1 and JAK2, STAT1 and STAT3, EGF-induced phosphorylation (activation) was detected and the inhibitory effect of PKG II was determined. For the EGF-induced gene transcription activity, expression of cell cycle-associated proteins and cell cycle process, the inhibitory effect of PKG II was also clearly demonstrated in the study. These results demonstrated the inhibitory effect of PKG II on EGF/EGFR-initiated signaling of the JAK/STAT-mediated pathway and further confirmed that PKG II exerts direct inhibitory activity of EGFR, and thus, exhibits wide-ranging inhibition of EGF/EGFR-initiated signal transduction and biological activities. The present results, and findings from previous studies, strongly indicate that PKG II is a potential inhibitor of EGFR and will provide novel insights into anti-cancer strategies.

\section{Acknowledgements}

This study was supported by the National Natural Science Foundation of China (grant nos. 81272755 and 81201959); Natural Science Foundation of Colleges and Universities in Jiangsu 
Province (grant no. 12KJB310001); the Specialized Research Fund for Senior Personnel Program of Jiangsu University (grant no. 11JDG114); Chinese Postdoctoral Science Foundation (grant no. 2014M561599); Postdoctoral research grants program of Jiangsu Province (grant no. 1401144C). The Innovation Grant of Jiangsu University (grant no. CXZZ13-0701). We thank Dr Gerry Boss and Dr Renate Pilz (University of California, San Diego, USA). for the kind gifts of adenoviral constructs.

\section{References}

1. Aaronson DS and Horvath CM: A road map for those who don't know JAK-STAT. Science 296: 1653-1655, 2002.

2. Hebenstreit D, Horejs-Hoeck J and Duschl A: JAK/STAT-dependent gene regulation by cytokines. Drug News Perspect 18: 243-249, 2005.

3. Hofmann F: The biology of cyclic GMP-dependent protein kinases. J Biol Chem 280: 1-4, 2005.

4. Cook AL and Haynes JM: Protein kinase G II-mediated proliferative effects in human cultured prostatic stromal cells. Cell Signal 16: 253-261, 2004.

5. Swartling FJ, Ferletta M, Kastemar M, Weiss WA and Westermark B: Cyclic GMP-dependent protein kinase II inhibits cell proliferation, Sox 9 expression and Akt phosphorylation in human glioma cell lines. Oncogene 28: 3121-3131, 2009.

6. Fallahian F, Karami-Tehrani F, Salami S and Aghaei M: Cyclic GMP induced apoptosis via protein kinase G in oestrogen receptor-positive and-negative breast cancer cell lines. FEBS J 278: 3360-3369, 2011.

7. Wu Y, Chen Y, Qu R, Lan T and Sang J: Type II cGMP-dependent protein kinase inhibits EGF-triggered signal transduction of the MAPK/ERK-mediated pathway in gastric cancer cells. Oncol Rep 27: 553-558, 2012.

8. Lan T, Chen Y, Sang J, Wu Y, Wang Y, Jiang L and Tao Y: Type II cGMP-dependent protein kinase inhibits EGF-induced MAPK/JNK signal transduction in breast cancer cells. Oncol Rep 27: 2039-2044, 2012

9. Xie Z, Peng J, Pennypacker SD and Chen Y: Critical role for the catalytic activity of phospholipase C-gammal in epiderma growth factor-induced cell migration. Biochem Biophys Res Commun 399: 425-428, 2010.

10. Dong P, Xu Z, Jia N, Li D and Feng Y: Elevated expression of p53 gain-of-function mutation $\mathrm{R} 175 \mathrm{H}$ in endometrial cancer cells can increase the invasive phenotypes by activation of the EGFR/PI3K/AKT pathway. Mol Cancer 8: 103, 2009.

11. Quesnelle KM, Boehm AL and Grandis JR: STAT-mediated EGFR signaling in cancer. J Cell Biochem 102: 311-319, 2007.
12. Morandell S, Stasyk T, Skvortsov S, Ascher S and Huber LA: Quantitative proteomics and phosphoproteomics reveal novel insights into complexity and dynamics of the EGFR signaling network. Proteomics 8: 4383-4401, 2008.

13. Makki R, Meister M, Pennetier D, Ubeda JM, Braun A, Daburon V, Krzemień J, Bourbon HM, Zhou R, Vincent A and Crozatier M: A short receptor downregulates JAK/STAT signalling to control the Drosophila cellular immune response. PLoS Biol 8: e1000441, 2010.

14. Barré B, Avril S and Coqueret O: Opposite regulation of myc and p21waf1 transcription by STAT3 proteins. J Biol Chem 278: 2990-2996, 2003.

15. Nichane M, Ren X and Bellefroid EJ: Self-regulation of Stat3 activity coordinates cell-cycle progression and neural crest specification. EMBO J 29: 55-67, 2010.

16. Wang YH and Huang ML: Organogenesis and tumorigenesis: Insight from the JAK/STAT pathway in the Drosophila eye. Dev Dyn 239: 2522-2533, 2010.

17. Aggarwal BB, Kunnumakkara AB, Harikumar KB, Gupta SR, Tharakan ST, Koca C, Dey S and Sung B: Signal transducer and activator of transcription-3, inflammation, and cancer: How intimate is the relationship? Ann N Y Acad Sci 1171: 59-76, 2009.

18. Xiong $\mathrm{H}, \mathrm{Du} \mathrm{W}$, Wang JL, Wang YC, Tang JT, Hong $\mathrm{J}$ and Fang JY: Constitutive activation of STAT3 is predictive of poor prognosis in human gastric cancer. J Mol Med (Berl) 90: 1037-1046, 2012.

19. Deng JY, Sun D, Liu XY, Pan Y and Liang H: STAT-3 correlates with lymph node metastasis and cell survival in gastric cancer. World J Gastroenterol 16: 5380-5387, 2010.

20. Normanno N, Bianco C, De Luca A, Maiello MR and Salomon DS: Target-based agents against ErbB receptors and their ligands: A novel approach to cancer treatment. Endocr Relat Cancer 10: 1-21, 2003

21. Hu T and Li C: Convergence between Wnt- $\beta$-catenin and EGFR signaling in cancer. Mol Cancer 9: 236, 2010.

22. Sharma SV, Bell DW, Settleman J and Haber DA: Epidermal growth factor receptor mutations in lung cancer. Nat Rev Cancer 7: 169-181, 2007.

23. Quatrale AE, Porcelli L, Silvestris N, Colucci G, Angelo A and Azzariti A: EGFR tyrosine kinases inhibitors in cancer treatment: In vitro and in vivo evidence. Front Biosci (Landmark Ed) 16: 1962-1972, 2011.

24. Jiang L, Lan T, Chen Y, Sang J, Li Y, Wu M, Tao Y, Wang Y, Qian $\mathrm{H}$ and Gu L: PKG II inhibits EGF/EGFR-induced migration of gastric cancer cells. PLoS One 8: e61674, 2013.

25. Wu M, Chen Y, Jiang L, Li Y, Lan T, Wang Y and Qian H: Type II cGMP-dependent protein kinase inhibits epidermal growth factor-induced phosphatidylinositol-3-kinase/Akt signal transduction in gastric cancer cells. Oncol Lett 6: 1723-1728, 2013. 